\title{
Oblicza ezoteryzmu
}

\begin{abstract}
Esoterism belongs to those phenomena present for a long time in culture which caused and still cause certain interest, as well different kinds of reservations and raise certain questions. The main issue is however made here by the fact that it had taken and still takes various forms and it is being perceived and presented differently by both - its followers and its academic researchers. In these remarks I will recall several exatmples of that. Although none of those researchers aren't willing to marginalize and trivialize the issue they do differ in the judgment of its cultural impact. I'm willing in that matter to share the general thesis by saying that it had played and still does an alternative role to the socially dominant forms of culture.
\end{abstract}

Keywords: esoterism, academic perception of esoterism, academic presentation of esoterism

Dopularność różnych form ezoteryzmu w dzisiejszej kulturze skłania do przyjrzenia się temu, co miał i ma on do zaoferowania nie tylko tzw. przeciętnemu człowiekowi, ale także tym, którzy stawiają wyższe wymagania temu, co pretenduje do miana wiedzy. Rzecz nie tylko tw tym, że są to istotnie różniące się propozycje, ale także w tym, że są one różnie postrzegane i oceniane przez tych, którzy zajmują się ich naukową analizą. W tych rozważaniach przywołam kilka przykładowych ujęć ezoteryzmu oraz jego naukowej oceny. 


\section{Kilka wstępnych wyjaśnień}

Zacząć trzeba jednak od pojęcia „ezoteryzm”. Etymologicznie wywodzi się ono z greckiego terminu esôterikós, oznaczającego „przynależność do wewnętrznego kręgu”. W kulturze zachodniej pojawiło się ono w II wieku n.e. w utworze satyrycznym Luciana z Samosaty ${ }^{1}$. W późniejszym okresie wprawdzie rzadziej po nie sięgano, jednak w XVIII i w XIX stuleciu zaczęło coraz częściej występować na kartach dzieł zarówno obrońców ezoteryzmu, jak i jego licznych krytyków. W drugiej połowie XIX i w XX stuleciu pojawiły się nie tylko jego naukowe analizy, ale także próby jego ocenienia i doceniania jego kulturowego znaczenia. W połowie minionego stulecia i na początku obecnego utworzone zostały na zachodnich uniwersytetach jednostki organizacyjne prowadzące systematyczne badania nad ezoteryzmem. Jedną z pierwszych była utworzona w 1964 roku przez Antoine’a Faivre’a sorbońska Szkoła Praktycznych Studiów Wyższych (École Pratique des Hautes Études). W 1999 roku na Uniwersytecie w Amsterdamie powołany został Instytut Badań Hermetyzmu (jego częścią była Katedra Historii Ezoteryzmu kierowana przez Woutera J. Hanegraaffa). W 2002 roku na Uniwersytecie Lampetera (UK) powstało Centrum Badań Zachodniego Ezoteryzmu. Natomiast w 2006 roku podobne centrum powstało na Uniwersytecie Exeter (UK). Tego typu jednostki badawcze istnieją również na Uniwersytecie w Lozannie, Uniwersytecie Marcina Lutra w Halle-Wittenberdze, Uniwersytecie Ludwika Maksymiliana w Monachium, oraz na kalifornijskim uniwersytecie w Davis. Wyniki prowadzonych w nich badań są prezentowane i dyskutowane m.in. na akademickich kongresach i konferencjach naukowych, takich jak kongresy organizowane przez American Academy of Religion czy International Association for the History of Religion (ostatni z nich odbywał się w 2019 roku w Rydze). Przyczyniły się one to do tego, że dzisiejsza wiedza o tym, czym był i jest ezoteryzm, okazuje się nie tylko głębsza, ale także bardziej uporządkowana, a jego oceny spełniają w większym stopniu niż jeszcze pół wieku temu wymogi naukowości. Rzecz jasna, ezoteryzm nadal pozostawia szereg znaków zapytania, a odpowiedzi na związane z nim pytania w dużej mierze zależą nie tylko od tego, którą z jego form będzie się miało na uwadze, ale także z jakiej perspektywy badawczej jest on analizowany i przedstawiany.

Jego akademiccy badacze generalnie zgodni są co do tego, że w badaniach nad ezoteryzmem zasadne jest przyjęcie perspektywy historycznej. Jednak w tej perspektywie mogą się pojawić nie tylko jego różne formy wyrazu, ale także różne sposoby ich naukowego objaśnienia i ocenienia. Trzeba przy tym jasno powiedzieć, że próby ich w miarę całościowego ujęcia wymagają takich kompetencji

${ }^{1}$ W.J. Hanegraaff, Western Esotericism: A Guide for the Perplexed. Guides for the Perplexed, Bloomsbury Academic, London 2013, s. 3 nn. 
badawczych, które w praktyce nie są możliwe do osiągnięcia przez pojedynczych uczonych. Stąd powoływane są zespoły badawcze składające się z uczonych o zróżnicowanych kompetencjach lub też zawęża się perspektywy badawcze do takiego obszaru, który jest możliwy do intelektualnego „ogarnięcia” przez któregoś ze specjalistów. Często jest to zawężenie do zachodniego ezoteryzmu. Nie rozwiązuje to jeszcze wszystkich tych trudności, na które napotykają uczeni specjalizujący się w badaniach nad tak wyodrębnionym ezoteryzmem. Jest on bowiem również ogromnie zróżnicowany i - co niemniej istotne - przechodził tak znaczące zmiany, że to, co mogło uchodzić za reprezentatywne dla którejś z jego form wcześniejszych, przestawało być reprezentatywne dla jego form późniejszych. Wywołuje to rzecz jasna różnorakie kontrowersje. Pokazują je m.in. rozbieżności w ujmowaniu i przedstawianiu zachodniego ezoteryzmu przez takich jego badaczy, jak Antoine Faivre, Wouder J. Hanegraaf i Kocku von Stuckard.

\section{Ezoteryzm w ujęciu Antoine'a Faivre'a}

Antoine Faivre jest autorem zarówno szczegółowych, jak i przeglądowych analiz i prezentacji wybranych form zachodniego ezoteryzmu². Dla celów badawczych wyróżnił on sześć jego generalnych cech: 1) taką wizję makro- i mikrokosmosu, w której istotną rolę przypisuje się działaniu planet; 2) przekonanie, że wszechświat jest „nasycony” taką siłą życiową, która sprawia, że jest on zróżnicowany jakościowo i ilościowo, oraz hierarchicznie uporządkowany; 3) wiarę w to, że określonego rodzaju praktyki umożliwiają dostęp do wyższego boskiego świata; 4) eksponowanie potrzeby takiej duchowej przemiany, która prowadzi do zjednoczenia z tym wyższym światem; 5) wiarę w to, że cała różnorodność i różnorakość świata może się zjednoczyć w jedność; oraz 6) wiarę w to, że w zgłębianiu ezoterycznych tajemnic można osiągnąć mistrzostwo, a mistrzowie swoją wiedzę mogą przekazywać swoim uczniom i sukcesorom poprzez odpowiedni proces inicjacji ${ }^{3}$. We wprowadzeniu do książki pt. Ezoteryzm przywołuje przykład próby wskazania

\footnotetext{
${ }^{2}$ Antoine Faivre jest również autorem: Kirchberger et l'Illuminisme du XVIIIe siècle, Nijhoff (Internationalm Archives for the History of Ideas, no. 16), Den Hag 1966; Eckartshausen et la théosophie chrétienne, Klincksieck, Paris 1969; L'ésotérisme au XVIIIe siècle en France et en Allemagne, Seghers-Laffont (La Table d’Émeraude), Paris 1973. Éd. espagnole : El Esoterismo en el siglo XVIII, Madrid, edaf, 1976; Mystiques, Théosophes et Illuminés au siècle des Lumières, Olms (Studien und Materialien zur Geschichte der Philosophie, Bd. 20), Hildesheim 1977; Les contes de Grimm (Mythe et Initiation), Les Lettres Modernes (Circé, Cahiers de Recherche sur l’Imaginaire, no. 10-11), Paris 1978; Accès de l'ésotérisme occidental, Paris, Gallimard ( "Bibliothèque des Sciences humaines »), 2 vol Alchimie, Paris-Milan, Archè, 1990; Physique sacrée et théosophie, XVIIIe-XIXe siècle), Albin Michel ("Idées philosophiques »), Paris 1996; Esoterismo e tradizione, Elledici (Religioni e Movimienti), Leumann (Turin) 1999.

${ }^{3}$ Por. A. Faivre, Access to Western Esotericism, Suny Press. New York 1994, s. 10 nn.
} 
listy cech „uniwersalnego ezoteryzmu” (określenie to jednak bierze w cudzysłów”) 4 . Uczonych podejmujących takie próby nazywa: „generalistami” - zalicza do nich zarówno Marco Pasiego, jak i Woudera J. Hanegraaffa. Jego zdaniem, wprawdzie „opublikowali oni prace o fundamentalnym znaczeniu dla badań nad ezoteryzmem”, jednak jego pojmowanie i przedstawianie „dopasowali do swojego modelu procedury postępowania badawczego i takich wiodących pojęć, jak »okultyzm« i »magia«”).

Sporządzona przez Faivre’a lista cech ezoteryzmu zachodniego spotkała się z uznaniem jednych jego badaczy oraz z zastrzeżeniami innych. Jednak nawet ci pierwsi zwracali uwagę na to, że jest ona przydatna do analizowanie i objaśniania jeśli nie wyłącznie, to przede wszystkim tych jego form, które analizował ten uczony5. Natomiast ci drudzy mieli zastrzeżenia nawet co do takiej przydatności, bowiem - jak twierdzi wspomniany już Hanegraaff - zakłada się w niej po, pierwsze, istnienie modelowego ezoteryzmu, a po drugie, do ezoteryzmu zalicza się wszystko to, co nie jest zgodne „z normatywnymi koncepcjami religii, racjonalności i nauki”; a normy te zostały zapożyczone z głównego nurtu XIX- i XX-wiecznej nauki ${ }^{6}$. Uczony ten zaproponował taką charakterystykę zachodniego ezoteryzmu, która wprawdzie pozwala nazwać niektóre z jego form „akademickim śmietnikiem odrzuconej wiedzy”, jednak nie pozwala go sprowadzić do takiego „śmietnika”. Było bowiem i jest nadal wiele takich jego form, które funkcjonowały poza akademickim życiem, a ich zwolennicy nie zabiegali specjalnie o uznanie tego środowiska.

Te różnice w charakteryzowaniu ezoteryzmu przekładają się na eksponowanie przez obu tych badaczy różnych jego form. Formy te Faivre w sposób syntetyczny przedstawił we wspomnianej tutaj książce pt. Ezoteryzm. Składa się ona z pięciu rozdziałów. Poprzedzone są one wprowadzeniem, w którym jej autor przedstawia różne możliwości rozumienia ezoteryzmu - począwszy od zaliczenia do niego wszystkiego tego, co się pojawia na półkach księgarń specjalizujących się w tego typu literaturze, poprzez podanie jego pojęciowych zamienników (np. „w języku angielskim często używa się etykiety - okultyzm lub metafizyka”; także często pojęcie ezoteryzm „stanowi synonim »wtajemniczenia«”), a skończywszy na tych „specyficznych trendach historycznych, które odwołują się do żydowskich i muzułmańskich tradycji (takich jak żydowska kabała), pism greckich z okresu późnej starożytności przypisywanych Hermesowi Trismegistosowi (w wersji zlatynizowanej: Hermes Trismegistus) oraz na chrześcijańskich gnostykach ${ }^{7}$. Tak nakreślone historyczne źródła ezoteryzmu oznaczają nie tylko jego zawężenie do tych jego form, które pojawiły się i rozwijały w kulturze zachodniej, ale także

${ }^{4}$ Podjął ją Pierre Riffard - do tych cech zaliczył on: opozycję między wtajemniczonymi i laikami, wtajemniczenie, channeling i inicjację. Zob. P.A. Riffard, L'ésotérisme: Qu'est-ce que l'ésotérisme. Anthologie de l'ésotérisme occidental, Robert Laffont Paris 1990, s. $15 \mathrm{nn}$.

${ }^{5}$ N. Goodrick-Clarke, The Western Esoteric Traditions: A Historical Introduction, Oxford University Press, Oxford 2008, s. 7 nn.

${ }^{6}$ W.J. Hanegraaff, Western Esotericism..., s. $13 \mathrm{nn}$.

7 A. Faivre, L'ésotérisme, Press Universitaire de France, Paris 1992, s. 1 nn. 
na eksponowaniu: 1) w okresie renesansu neoaleksandryjskiego hermetyzmu, chrześcijańskiej kabały, okultyzmu, alchemii oraz różokrzyżowców; 2) w okresie Oświecenia teozofii, iluminizmu, magnetyzmu zwierzęcego, oraz systemu masońskiego rytu szkockiego; 3) w XIX stuleciu okultyzmu i teozofii; 4) w XX stuleciu tej nowej formy gnozy, która aspirowała do roli „nowej pansophie”.

W kolejnych częściach tej książki znajdują się uszczegółowione obrazy wyróżnionych przez jej autora form ezoteryzmu. Przykładowo: w rozdziale II, zatytułowanym $W$ sercu renesansu $i$ w ogniu baroku, eksponowany jest Marsilo Ficino oraz jego rola w przywróceniu kulturowej roli Corpus Hermeticum, w tym występującej w niej idei „wiecznej filozofii”. W rozdziale III - zatytułowanym Ezoteryzm w cieniu Oświecenia, prezentowana jest zarówno „teozofia w całej okazałości” (reprezentowana m.in. przez Gottfrieda Arnolda, Jacoba Bruckera, Jakoba Böhme) oraz jej związki z pietyzmem, mistycyzmem oraz ruchem masońskim w rycie szkockim („narodził się on jednak w 1717 roku w Londynie). W jej rozdziale IV, zatytułowanym Od wiedzy romantycznej do programów okultystycznych, eksponowany jest zarówno naturalistyczny „magnetyzm zwierzęcy”, jak i spirytualistyczny okultyzm teozofów. Natomiast w rozdziale V, zatytułowanym Ezoteryka XX wieku, na pierwszym planie znajduje się chrześcijańska teozofia i te formy gnozy, które miały aspiracje bycia „nową pansophią”.

\section{Ezoteryzm w ujęciu Woutera J. Hanegraaffa}

Perspektywa badawcza przyjęta przez Woutera J. Hanegraaffa w książce pt. Esotericism and the Academy wynika nie tylko ze specyfiki rozumienia przez jej autora tego kulturowego zjawiska, ale także z faktu, że przedmiotem jego zainteresowania są te jego formy, które usytuowały się w stosunkowo niedużej odległości od nauki, a niektóre z nich nawet pretendowały do stania się jej integralną częścią ${ }^{8}$. Za ich prekursora i intelektualnego patrona uznaje on Platona. Założona przez niego ok. 387 r. p.n.e. w Atenach akademia stanowiła swoisty pierwowzór zarówno dla późniejszych platoników, jak i tych uczonych, którzy albo dokonywali istotnych korekt poglądów tego starożytnego filozofa, albo też z nimi zrywali, jednak przejmowali od niego ten sposób organizowania się we wspólnoty wtajemniczonych, który nazwany został akademią. Jednym z takich wyróżnionych przez Hanegraaffa platoników był George Gemistos Plethon (nazywany przez niego „mędrcem ze Wschodu”), natomiast inni renesansowi platonicy to Marsio

${ }^{8}$ Por. W.J. Hanegraaff, Esotericism and the Academy. Rejected Knowledhe in Western Culture, Cambridge University Press, Cambridge 2012. Wouter J. Hanegraaff jest również autorem: New Age Religion and Western Culture (1996); Lodovico Lazzarelli (1447-1500) (with R.M. Bouthoorn, 2005); Dictionary of Gnosis and Western Esotericism (2005), andco-editor of six other books including Hidden Intercourse: Eros and Sexuality in the History of Western Esotericism (co-edited with Jeffrey J. Kripal, 2008). 
Ficino (nazywany „teologiem platonicznym”) oraz Giovanni Pico della Mirandola (nazywany „tajemniczym Mojżeszem”). Zarówno ten pierwszy, jak i ten drugi byli członkami reaktywowanej we Florencji w roku 1462 Akademii Platońskiej ${ }^{9} \mathrm{O}$ ile jeszcze związki tych myślicieli z tradycją platońską nie budzą poważniejszych zastrzeżeń, to już zaliczenie do członków platońskiej akademii Agostino Steuco (nazywanego „uniwersalnym katolikiem”) oraz Jacoba Thomasius (nazywanego „antyapologetą”) może wywołać poważne zastrzeżenia znawców tej filozoficznej tradycji. Największym zaskoczeniem może być jednak umieszczenie w tym gronie oświeceniowego medyka i autora teorii, która przeszła do historii pod nazwą „magnetyzmu zwierzęcego” Franza Antona Mesmera (1734-1815). Problem nie w tym, że nie można go zaliczyć do ezoterystów (zalicza go do nich również Faivre), lecz w tym, że był on - jak zresztą wielu innych przedstawicieli tamtej epoki - zwolennikiem naturalizmu, a o Platonie i platonikach w żadnym razie nie można powiedzieć, że podpisaliby się oni pod naturalistycznymi założeniami i postulatami. Mniejsza zresztą o tę niezgodność. Znacznie bardziej interesujące jest bowiem to, w jaki sposób w tym „magnetyzmie zwierzęcym” oświeceniowy naturalizm połączony został z ezoteryzmem. Jakąś próbkę tego łączenia daje przywołany przez Hanegraaffa ten fragment Krótkiej historii Mesmera, w którym daje on świadectwa zarówno swojemu podziwowi dla Natury, jak i swojej wierze w to, że istnieje w niej taka „siła życiowa”, która pośredniczy miedzy duchem i materią, a jej tajemnice mogą być poznane nie za sprawą racjonalnego dyskursu, lecz za pomocą sztucznie wywoływanych ekstatycznych stanów ${ }^{10}$.

Od mesmeryzmu jest już stosunkowo niedaleka droga do tej teorii snów, którą sformułował i upowszechniał szwajcarski psychiatra Carl Gustaw Junga (18751961), profesor w Klinice Psychiatrii Uniwersytetu Zuryskiego. Hanegraaff łączy go z grupą dyskusyjną, która funkcjonowała pod nazwą Eranos; określenie to wzięte zostało ze starogreckiego pojęcia épavoc, oznaczającego taki bankiet, na który goście przynoszą jedzenie. Inicjatorką jej powstania w 1933 roku była Olga Froebe-Kapteyn (zdaniem Hanegraaffa była ona „pod wpływem ówczesnej teozofii i innych form ezoteryki”). Spotkania te odbywały się corocznie (aż do 1988 roku) w posiadłości ich inicjatorki położonej w pobliżu Ascony w Szwajcarii. Według Hanegraaffa pierwszy okres funkcjonowania Eranosa „można nazwać erą Junga”, bowiem ten szwajcarski psycholog był na nich postacią dominującą ${ }^{11}$. W okresie tym ich uczestnicy koncentrowali się wokół problemu znaczenia mitu w historii oraz

${ }_{9}^{9}$ Por. Z. Drozdowicz, Filozofia włoska w epoce Odrodzenia I Oświecenia, Wydawnictwo Naukowe WNS UAM, Poznań 2012, s. 45 nn.

${ }^{10}$ Por. W.J. Hanegraaff, Esotericism and the Academy..., s. 260 nn.; F.A. Mesmer, Kurze Geschichte des thierischen Magnetismus bis April 1781, Michael Macklot, Karlsruhe 1783. Szerzej w kwestii tej teorii: R. Darnton, Mesmerism and the End of the Enlightenment in France, Harvard University Press, Cambridge 1968.

${ }^{11}$ Jednak „obok szeregu innych ważnych myślicieli, w tym indologa Heinricha Zimmera, teologa Friedricha Hellera, historyka religii Jacoba Wilhelma Hausera, filozofa Martina Bubera, 
we współczesnej kulturze, a także zasadności oświeceniowych prób ustanowienia racjonalności poprzez wykluczenia ezoteryzmu z kultury lub też - co na to samo wychodzi - „umieszczaniu go w koszu na śmieci”. Według występującemu przeciwko takiemu traktowaniu ezoteryzmu Junga stanowiło to wyraz „stłumienia tej »innej « zachodniej racjonalności, której źródłem była sama nieświadomość człowieka, zarówno na poziomie zbiorowym, jak i jednostkowym”. Hanegraaff analizując nieco bardziej szczegółowo poglądy Junga, zwraca uwagę miedzy innymi na jego przekonanie, że „ludzki sen jest mitem jednostki”, a jego „interpretacja kluczem do psychologicznego uzdrowienia”, natomiast „zbiorowe archetypy i zbiorowa nieświadomość wynikają z tej samej logiki, tj. logiki obrazów i narracji, które pamiętamy jako sny” ${ }^{12}$. Aspiracje badawcze Junga szły jednak znacznie dalej niż znalezienie i objaśnienie tego „klucza do psychologicznego uzdrowienia”, bowiem poszukiwał również takiej „prawdy historii”, w której znajduje się zarówno objaśnienie sensu historycznej walki między pogaństwem i biblijnym chrześcijaństwem, jak i historyczny „most” między gnostycyzmem i neoplatonizmem, oraz prowadzi do współczesnej mu psychologii nieświadomości. Ten kierunek poszukiwań kontynuowany był przez młodsze pokolenie uczestników spotkań Eranosa, takich jak badacz żydowskiego mistycyzmu Gershom Scholem (1897-1982), orientalista Henry Corbin (1903-1978) oraz religioznawca Mircea Eliade (1907-1986) ${ }^{13}$.

\section{Ezoteryzm w ujęciu Maxa Webera}

W spotkaniach dyskusyjnych grupy Eranosa brał udział również Max Weber (18641920), autor między innymi napisanego we wczesnym okresie pracy badawczej eseju pt. Etyka protestancka a duch kapitalizmu oraz napisanego w późniejszym okresie fundamentalnego dzieła pt. Etyka gospodarcza religii światowych. Pierwsza z tych rozpraw przyniosła mu spory rozgłos w środowisku akademickim. Jednak za swoje dzieło życia uważał tę drugą. Wspólnym mianownikiem dla obu dzieł jest próba pokazania historycznego procesu kreowania różnych form racjonalności i przeciwstawiania ich zastanym formom irracjonalizmu w ludzkich wierzeniach i w podejmowanych działaniach. Natomiast tym, co je różni, są wybrane przez Webera historyczne okresy, jak i miejsca ich występowania. W Etyce protestanc-

islamisty Louisa Massignona i badaczy mitologii, takich jak Walter F. Otto, czy Karl Kerenyi”. Ibidem, s. 278.

${ }^{12}$ Ibidem, s. 284. Por. C.G. Jung, Symbols of Transformation: An Analysis of the Prelude to a Case of Schizophrenia, Princeton University Press, Princeton 1956.

13 „Scholem ostatecznie poświęcił »prawdę« w interesie historii, podczas gdy Corbin poświęcił historię w interesie "prawdy (ten pierwszy z żalem, natomiast ten ostatni ze smakiem). Trzecia centralna postać Eranosa w okresie powojennym Mircea Eliade wydaje się raczej reprezentować nierozwiązywalny paradoks religii jako takiej; jak często zauważano, dyscyplina, którą nazwał »historią religii« stanowi próbę przekroczenia historii” . W.J. Hanegraaff, Esotericism and the Academy..., s. 302. 
kiej zostają one zawężone do zachodniej kultury europejskiej, w szczególności tego jej okresu, w którym do głosu doszły różne formy protestanckiej reformy religii chrześcijańskiej ${ }^{14}$. Natomiast w Etykach gospodarczych religii światowych analizuje on i prezentuje procesy racjonalizacji występujące w takich starożytnych religiach, jak: taoizm i konfucjanizm, hinduizm i buddyzm oraz starożytny judaizm. Zarówno w tym pierwszym, jak i w tym drugim dziele wskazuje on na różne formy ezoteryzmu $\mathrm{i}$ jego rolę $\mathrm{w}$ tym procesie racjonalizacji ludzkiego myślenia, działania oraz życia i współżycia społecznego ${ }^{15}$.

W Etyce protestanckiej Weber starał się wykazać, że występujące w kulturze zachodniej formy racjonalizmu pozostawały w związku nie tylko z rozwiniętymi dyscyplinami naukowymi (takimi jak geometria, czy nauki przyrodnicze), ale także z zachodnią sztuką (taką jak muzyka czy architektura), zachodnim prawodawstwem (wyrażającym się między innymi w „racjonalnie sformułowanej »konstytucji«, racjonalnie opracowanym prawie i administracji ukształtowanej według racjonalnych reguł”), oraz w religii chrześcijańskiej, w szczególności w tej jej etyce, która zachęcała do czynnego udziału w życiu społecznym, w tym do aktywności gospodarczej. Za przełomowe wydarzenie historyczne uznał on pojawienie się w kulturze zachodniej „,zterech nurtów ascetycznego protestantyzmu: „1. Kalwinizmu (w takiej postaci jaką przyjął w Europie Zachodniej); 2. Pietyzmu; 3. Metodyzmu; oraz 4. Sekto wyrosłym z ruchu nowochrzczeńców”16. W każdym z tych nurtów znajdował on jakieś elementy ezoteryzmu i to ezoteryzmu bardziej konstruktywnego niż ten, który był udziałem tych form praktykowania religii chrześcijańskiej, w których chrześcijanie „uciekali od tego świata w samotność” i zamykali się w murach klasztornych. Stosunkowo najwyżej oceniany jest przez Webera ten ezoteryzm, który praktykowali i upowszechniali angielscy purytanie, mający swoich liderów między innymi w osobach Richarda Baxtera (,jego Christiane Directory to najlepsze kompendium purytańskiej teologii moralnej”) oraz Roberta Barcleya („,przedstawiciela teologii kwakrów”). U obu teologów „rzucają się w oczy ebionickie elementy przekazu nowotestamentowego”, wyrażające się nie

${ }^{14}$ „Weberowska nauka o ascetycznym protestantyzmie i nowoczesnej zawodowej kulturze nie jest ani badaniem pochodzenia nowoczesnego kapitalistycznego systemu ekonomicznego lub - bardziej ogólnie - nowoczesnej społecznej organizacji, ani też zmierza ona do wyjaśnienia pochodzenia nowoczesnego teoretycznego racjonalizmu nowoczesnej nauki. Jego nauka dotyczy raczej jednego przyczynowo ważnego czynnika pochodzenia praktycznego racjonalizmu oraz wynikającej stąd ludzkiej skłonności do angażowania się w "praktyczne racjonalne zachowanie» określonego rodzaju, w określony styl życia takiego wewnątrzświatowego ascetyzmu, który łączą aktywną samokontrolę z mistrzostwem świata”. Por. W. Schluchter, The Rise of Western Rationalism, Cambridge Press, Berkley-Los Angeles-London 1985, s. 141 nn.

${ }^{15}$ Szczegółową analizy porównawczą tych różnie lokowanych przez M. Webera procesów racjonalizacji przeprowadził Alan Sica. Zob. A. Sica, Weber. Irrationality and Social Order, Berkeley-Los Angeles-London 1988.

${ }_{16}$ Por. M. Weber, Etyka protestancka a duch kapitalizmu, Wydawnictwo Test, Lublin 1994, s. $77 \mathrm{i}$ in. 
tylko w przypisywaniu „przemożnego znaczenia Królestwu Bożemu” i ludzkiemu pragnieniu znalezienia się w nim, ale także w opowiedzeniu się za praktykowaniem takiej ascezy, która jest skierowana przeciwko ,jakiemukolwiek dążeniu do gromadzenia dóbr doczesnych” ${ }^{17}$. W odróżnieniu od angielskich purytan, niemieccy pietyści (między innymi A.H. Francke, F.J. Spener czy L. von Zinzendorf) „nie ufając Kościołowi teologów [...], chcieli niewidzialny Kościół świętych ściągnąć na ziemię i, nie wyciągając konsekwencji sekciarskich, prowadzić w tych wspólnotach oddalonych od wpływów świata życie zorientowane we wszystkim na wolę bożą, aby osiągnąć przez to pewność własnego odrodzenia również w tych codziennych, zewnętrznych objawach”"

Weber po napisaniu Etyki protestanckiej rozpoczął realizację projektu badawczego, obejmującego badania nad tymi procesami racjonalizacji, które występowały w starożytnych kulturach poprzedzających kulturę zachodnią oraz w różny sposób na nią wpływających ${ }^{19}$. W szczególności wpłynął na nią starożytny judaizm. Stąd jego analiza i prezentacja w Etykach gospodarczych religii światowych zajmuje stosunkowo najwięcej miejsca ${ }^{20}$. Wprawdzie ezoteryzm nie jest w Starożytnym judaizmie problemem „kluczowym” (zdaniem Johna Love’a, stanowi go „sprawa tej jedności, która zjednoczyła pierwotne plemiona Izraela i doprowadziła je do politycznego przymierza”), to jednak jest on w nim niejednokrotnie przywoływany i to w różnych formach wyrazu. Jedną z nich była „rozpowszechniona w Babilonie ezoteryczna wiara w zmartwychwstanie, uwarunkowana przez mity astralne, która pojawia się nagle w Księdze Daniela w zupełnie rozwiniętej formie i po epoce Machabeuszy staje się wiarą ludową (faryzejską)”21. Inną jego formą jest

17 „Można w literaturze purytańskiej dowolnie mnożyć przykłady potępienia dążności do pieniędzy i majątków oraz porównywać je z etyczną literaturą średniowieczną, pod tym względem o wiele bardziej tolerancyjną”. Ibidem, s. 148.

18 „Dążenie to miało w sobie coś podobnego do luterańskiego unio mystica i prowadziło do silniejszego akcentowania strony uczuciowej religii, aniżeli ma to normalnie miejsce w chrześcijaństwie reformowanym”. Ibidem, s. 118.

${ }_{19}$ Planowane badania przedstawił nie tylko swoim aktualnym współpracownikom (takim jak Ernst Troelsche), ale także współpracowniklom potencjalnym. W sporządzonym przez niego (prawdopodobnie w 1909 roku) i rozesłanym do potencjalnych współpracowników programie badawczym znajdują się m.in. badania nad kulturami Wschodu. Por. W. Schluchter, The Rise of Western Rationalism, s. $139 \mathrm{nn}$.

${ }^{20}$ Zdaniem Johna Love, ta część Etyk gospodarczych stanowi „prawdopodobnie najwspanialsze dzieło Webera”. W swojej prezentacji Starożytnego judaizmu zwraca on uwagę na to, że „już w Etyce protestanckiej Weber podkreślał związki pomiędzy judaizmem a światopoglądem purytańskim, sugerując, że ascetyczny purytanizm odziedziczył »perfekcyjną beznamiętność mądrości Żydów. [...] Starożytny judaizm można także odczytywać jako odpowiedź Webera skierowaną ku Nietzschemu w dość rozległej kwestii "genealogii moralności« oraz ogólnego znaczenia judeochrześcijańskiej tradycji dla losu zachodniej współczesności”. J. Love, Max Weber's Ancient Judaism, w: The Cambridge Companion to Weber, ed. S. Turner, Cambridge University Press, Cambridge 2000, s. $200 \mathrm{nn}$.

${ }^{21}$ Por. M. Weber, Starożytny judaizm, w: Socjologia religii, Dzieła zebrane, Zakład Wydawniczy Nomos, Kraków 2006, s. 639 nn. 
ta ezoteryka, która związana była „z wróżeniem z wnętrzności, obserwacji lotu ptaków lub innych zachowań zwierzęcych”. Jeszcze inną ta, która „opierała się na prestiżu magii” i która była „systematycznie zwalczana przez nauczycieli Tory” (takich jak lewici, którym „chodziło o racjonalną wiedzę etyczną, a nie rytualną czy ezoteryczną”). Stosunkowo najbardziej „zawikłana” była ezoteryka związana z nauczaniem żydowskich proroków (takich jak Izajasz czy Amos) o roli Jahwe, bowiem można było z tego nauczania wyprowadzić dwie „koncepcje osoby bohatera”. W świetle pierwszej z nich „Jahwe sam wprowadzi w życie swoje plany wobec wrogów”, natomiast w świetle drugiej w tej roli w ,jego imieniu wystąpi bohater eschatologiczny”; „prowadziło to albo w kierunku profetyzmu zbawienia (głównie w Jerozolimie, gdzie przedmiotem tych nadziei byli Dawidydzi), albo w kierunku ezoterycznych mitologemów. Wtedy zbawca stawał się postacią transcendentną"22. Zarówno w tym pierwszym, jak i w tym drugim przypadku nie chodziło jednak tylko o pokonanie wrogów Izraela, ale także o problem „wyjątkowej” relacji Izraelitów z Bogiem oraz o racjonalizację żydowskiego prawa i rolę w niej kapłanów.

W końcowych partiach tego dzieła do roli głównych racjonalizatorów judaizmu urastają „rabbi”: „stanowili oni warstwę intelektualistów o przeważająco plebejskim charakterze” i byli przeciwnikami żydowskich magów, mystagogów oraz „ezoterycznych filozofów, astrologów i augerów ${ }^{23}$. Warto jeszcze zwrócić uwagę na powiązanie przez Webera problemu żydowskiej racjonalizacji z problem „narodu pariasów”. Jego zdaniem, jego źródła należy również szukać w starożytnym judaizmie, w tym „w narzucaniu nakazów rytualnych, wypracowanych przez gminę babilońskich wygnańców” i to zamieszkałych w miastach ${ }^{24}$. John Love, oceniając generalnie weberowską wizję starożytnego judaizmu, przyznaje, że „niektóre jej części wywołują pewne zastrzeżenia”. Natomiast występująca w niej „koncepcja pariasów powinna być w całości lub częściowo odrzucona”. Dodaje on jednak, że „gdyby Weber mógł w pełni zrealizować swój zamiar i dokończyć swoje ostatnie prace na temat faryzeuszy i talmudycznego judaizmu, to jego spojrzenie na te kwestie byłyby nadal do zaakceptowania ${ }^{25}$.

22 Ibidem, s. $699 \mathrm{nn}$.

23 „Nie byli też nosicielami ezoterycznej wiedzy zbawczej, gnozy. Zakazana i potępiana przez nich była nie tylko szczególna forma gnozy przednioazjatyckiej, z jej demiurgami i anomizmem, ale także, przynajmniej w okresie klasyczno-talmudycznym, w ogóle wszelka gnoza”. Ibidem, s. $805 \mathrm{nn}$.

24 „Nie tylko dlatego, że szabat, rok szabatowy i przepisy żywieniowe były same w sobie trudne do przestrzegania w warunkach wiejskich, lecz przede wszystkim dlatego, że wraz z kazuistycznym rozwinięciem przykazań wyznaczających zasady zachowania, niezbędnym do prowadzenia poprawnego życia musiało stać się pouczanie o rytuale”. Ibidem, s. 783.

25 „Na jego obronę należy jednak jeszcze raz powiedzieć, że Weber w żadnym razie nie był antysemitą i w podobnym tonie, obiektywnym i pozbawionym sentymentów, wypowiadał się także o innych religiach”. J. Love, Max Weber's Ancient Judaism, s. 212. 


\section{Ezoteryzm ruchu New Age}

Ruch New Age stosunkowo największą popularnością cieszył się w latach 60. i 70. minionego stulecia. W tamtym czasie pojawiły się takie cieszące się popularnością publikacje, jak Revelation: The Birth of a New Age Davida Spranglera, oraz takie sztandarowe organizacje tego ruchu, jak Fundacja Finhorn (założona została ona w 1962 roku w Szkocji). Pojawiał się on zarówno w środkach masowego przekazu, jak i w akademickich dyskusjach o nowych ruchach religijnych. Obecnie ma on wprawdzie nadal swoich zwolenników, ale są to raczej stosunkowo nieliczne grupy osób skupiające się na zgłębianiu newage’owskich nauk i praktykowaniu channelingu, rozumianego m.in. jako nawiązywanie w różny sposób kontaktów z taką wyższą istotą, która jest traktowana jako duchowy przewodnik ${ }^{26}$. Natomiast w środowisku akademickim jest on przedmiotem zainteresowania głównie kulturoznawców i religioznawców; w każdym razie głownie oni podejmują próby wyjaśnienia zarówno jego genezy, jak i miejsca we współczesnej kulturze. Związanych z tym ruchem znaków zapytania pozostaje jednak nadal wiele. Podejmuje się jednak próby nie tylko ich uchylenia, ale także takiego określenia ruchu New Age, które byłoby możliwe nie tylko do zrozumienia przez zwyczajnych ludzi, ale także do zaakceptowania przez akademickich specjalistów. Jedną z takich prób jest jego definicyjne określenie w Encyklopedii Britannika. W tym świetle New Age jest ruchem kulturowym okultystycznych i metafizycznych wspólnot religijnych, które rozprzestrzeniły się w latach 70. i 80. XX wieku. Oczekiwano, że Nowa Era (nazywana Erą Wodnika) będzie erą miłości i światła, oraz osobistej przemiany duchowej i uzdrowienia. Najbardziej znaczący przedstawiciele tego ruchu byli zwolennikami nowoczesnego ezoteryzmu, w tym takiej perspektywy religijnej, która jest oparta na mistycznej wiedzy i która była popularna na Zachodzie w II wieku naszej ery, zwłaszcza w postaci gnostycyzmu. W późniejszym okresie ten starożytny gnostycyzm został zastąpiony przez różne ruchy ezoteryczne, w tym przez różokrzyżowców w XVII wieku i masonerię, oraz teozofię i rytualną magię w XIX i XX wieku”. Wprawdzie przyznaje się w tej definicji, że ruch ten „zjednoczył różnorodne grono wierzących” w nadejście Nowej Ery, to jednak dodaje się przy tym, że wspólna była dla nich wiara w to, że era ta będzie oznaczała osiągnięcie „wyższej świadomości duchowej oraz międzynarodowego pokoju, który położy kres rasizmowi, biedzie, chorobom, głodowi i wojnie”27. W definicji tej nie pozostawia się wątpliwości co do tego, że New Age wywodzi się z ezoterycznych tradycji kultury zachodniej, oraz stanowi jego nowoczesną wersję. Wątpliwości takie mają jednak niektórzy badacze tego ezoteryzmu.

${ }^{26}$ Por. J.P. Newport, The New Age Movement and the Biblical Worldview: Conflict and Dialogue, B. Eerdmans Publishing, Grand Rapids 1998, s. 154 nn.

${ }^{27}$ Por. New Age movement, www.britannica.com. 
Jednym z nich jest religioznawca z Uniwersytetu Groningen, Kocku von Stuckrad $^{28}$. W jego książce pt. Western Esotericism: A Brief History of Secret Knowledge New Age pojawia się w jej części ostatniej, zatytułowanej Ezoteryzm i nowoczesność. Stawia on jednak przy nim znak zapytania. Dotyczy on zarówno jego pojmowania, jak i jego nowoczesności oraz zasadności łączenia z ezoteryką. Kocku von Stuckard zauważa na wstępie, że

[...] każdy coś słyszał o New Age i łączy go z ezoteryką, jednak nikt tak naprawdę nie wie, co oznacza ten termin. Co gorsza, to pojęciowe zamieszanie dotyczy nie tylko popularnego pojmowania New Age, ale także świata akademickiego. [...] Niestety pod wspólny termin „New Age” podpada tak wiele różnych prądów, grup i tożsamości, że każda próba jego usystematyzowania wydaje się być sztucznym zabiegiem²9

Przypomina on przy tym, że „,idea następowania epok jest taka stara jak historia Europy”. Jednak użycie określenia „nowa epoka” sięga XIX wieku (pojawiło się ono w 1804 roku w napisanej przez Williama Blake’a przedmowie do wiersza angielskiego poety Miltona) ${ }^{30}$. Pewne znamiona nowości dostrzega on w lansowanej przez zwolenników tego ruch idei channelingu. Jednak idei tej nadaje się niejednokrotnie istotnie różniące się znaczenia; np. według Dana Browna, autora powieści Kod Leonarda da Vinci, oznacza ona osiągnięcie takich stanów świadomości, które oznaczają „uchwycenie energii z innych czasów i wymiarów”.

Odpowiadając na pytanie, jaki związek mają newage’owskie wierzenia i praktyki z ezoteryzmem, von Stuckrad stwierdza, że generalnie łączy je z nim holistyczne podejście do natury. Takie podejście jest jednak charakterystyczne również dla tej „głębokiej ekologii”, która „łączy etykę, politykę, biologię i duchowość”31. Przyznaje on, że występuje związek miedzy „myśleniem New Age” oraz „sakralizacją

${ }^{28}$ Kocku von Stuckard jest autorem również: Frömmigkeit und Wissenschaft: Astrologie in Tanach, Qumran und frührabbinischer Literatur' (Europäische Hochschulschriften XXIII/572). Peter Lang, Frankfurt a. M. etc. 1996; Das Ringen um die Astrologie: Jüdische und christliche Beiträge zum antiken Zeitverständnis (Religionsgeschichtliche Versuche und Vorarbeiten 49), Walter de Gruyter, Berlin \& New York 2000; Schamanismus und Esoterik: Kultur- und wissenschaftsgeschichtliche Betrachtungen, Gnostica: Texts and Interpretations 4, Peeters Leuven 2003. Geschichte der Astrologie: Von den Anfängen bis zur Gegenwart, C.H. Beck, Munich 2003, revised edition 2007; Was ist Esoterik? Kleine Geschichte des geheimen Wissens, C.H. Beck, Munich 2004.

${ }^{29}$ K. von Stuckrad, Western Esotericism: A Brief History of Secret Knowledge, Equinox London 2005, s. $140 \mathrm{nn}$.

30 „Później termin ten został spopularyzowany w książkach teozofki Alice Baily, a powszechnie znany stał się za sprawą amerykańskich publikacji wspierających kalifornijski ruch protestacyjny lat 60. i wczesnych lat 70. [...] wielu ludzi zafascynował pomysł, że Ziemia przechodzi proces takiej transformacji, która sprawi, że nieuchronnie powstanie nowa świadomość. Nawet jeśli Era Wodnika faktycznie odnosiła się do wiosennego przejścia punktu równonocy z Ryb w Wodnika, to szybko termin ten stracił wąską astrologiczną konotację”. Ibidem.

31 „Głęboka ekologia odnosi się zatem do tych najnowszych pomysłów w biologii, w których traktuje się współzależność ekosystemów jako przedmiot badań”. Ibidem, s. 143. 
jaźni” dokonaną przez G. Junga. Jednak wielu psychologów transpersonalnych stanowczo przeciwstawia się łączeniu ich zarówno z ezoteryzmem starszej daty (takim jak mesmeryzm), jak i młodszej daty (takim jak New Age). W podsumowaniu tej części książki pt. Western Esotericism jej autor napisał, że „na pierwszy rzut oka może się wydawać, że ruch transpersonalny zabrał nas daleko od ezoterycznych pomysłów Marsilio Ficino, Emanuela Swedenborga czy Heleny Bławatskiej. Jednak przy bliższym przyjrzeniu się widzimy, że transpersonalna psychologia, podobnie jak channeling i głęboka ekologia, zasadniczo kontynuują ezoteryczne projekty, tyle tylko że w inny sposób”.

Na nawiązywanie zwolenników ruchu New Age do tradycji zachodniego ezoteryzmu wskazuje również Hanegraaff w książce pt. New Age Religion and Western Culture: Esotericism in the Mirror of Secular Thought („,u większość z nich jednak jest zaskakująco niska świadoma nawiązywania do tych historycznych korzeni”). Problem nie tylko w owym braku zwolennikom New Age świadomości „historycznego zakorzenienia” tego ruchu, ale także w tym, że różni jego przedstawiciele głoszą tak różne poglądy, że nie można go uznać za jednolitą ideowo formację. Problem również w tym, że różni jego badacze tak różnie go przedstawiają, że można go kojarzyć niemal z każdą formą ezoteryzmu ${ }^{32}$. Hanegraaff zalicza go do takiej formy kultury popularnej, która stanowi krytykę tych dominujących w kulturze zachodniej wartości, które pojawiły się za sprawą z jednej strony religii judeochrześcijańskiej, natomiast z drugiej zachodniego racjonalizmu. W przywoływanej tutaj książce wskazuje on między innymi na znaczącą rolę okultyzmu w wykreowaniu ruchu New Age (jego zdaniem, można go nawet uznać za współczesną formę okultyzmu), chrześcijańskiego mistycyzmu (w szczególności mistycyzmu Emanuela Swedenborga) oraz mesmeryzmu. Za bezpośrednich poprzedników ruchu New Age Hanegraaff uznaje zwolenników „religii UFO” (nazywa ich nawet „ruchem proto-New Age”) ${ }^{33}$. Natomiast za ruchy współistniejące z nim lub nawet występujące w jego ramach uznaje on: Medytację Transcendentalną, Soka Gakkai, Ruch Wewnętrznego Pokoju oraz Kościół Wszystkich Światów. Rozróżnia on przy tym New Age w węższym i szerszym znaczeniu; w tym ostatnim zalicza do niego nie tylko głoszone przez jego zwolenników poglądy, ale także popularyzowanie go poprzez new-age'wskie publikacje oferowane w księgarniach tego ruchu, oraz różnego rodzaju gadżety sprzedawane w jego sklepach ${ }^{34}$. Za integralną część różnych form wyrazu ruchu New Age uznaje on: 1) wiarę w istnienie różnie pojmowanej i nazywanej boskości (niejednokrotnie występuje ona pod nazwą „energii”); 2) przekonanie, że nie może ona być pojęta ludzkim rozumem; 3) holistyczne ujmowanie rzeczywistości (określanej niekiedy jako „ocean

${ }^{32}$ W.J. Hanegraaff, New Age Religion and Western Culture: Esotericism in the Mirror of Secular Thought, Brill, Leiden 1996, s. $1 \mathrm{nn}$.

${ }^{33}$ Por. ibidem, s. $95 \mathrm{nn}$.

${ }^{34}$ Por. ibidem, s. $126 \mathrm{nn}$. 
jedności”); oraz 4) przekonanie, że owa rzeczywistość jest wypełniona miłością. Do tego dochodzi idea channelingu, traktowana jako „forma wyartykułowanego objawienia”35. Te wierzenia i przekonania znajdują się w opozycji zarówno wobec chrześcijańskiego dualizmu duszy i ciała, jak i takiego naturalistycznego monizmu, w którym redukuje się to, co duchowe do tego, co cielesne. Hanegraaff wskazuje również na nawiązywanie ruchu New Age do pseudonaukowych teorii (takich jak głoszona przez Gaia J. Lavelocka teoria, że Ziemia posiada zarówno świadomość, jak i inteligencję) oraz na próbę wylansowania przez jego zwolenników nowych paradygmatów naukowości. W sumie znajduje on jednak w tym ruchu zarówno pewne elementy racjonalności (występują one między innymi w jego „głównym nurcie leczniczym”, opowiadającym się za holistycznym uzdrawianiem) oraz irracjonalności (wyrażające się między innymi w irracjonalnej wierze w różnego rodzaju istoty pozaziemskie i „duchy natury”).

\section{Kilka ogólniejszych uwag i sugestii}

Pierwsza z tych uwag wiąże się z pytaniem o uwarunkowania kreślenia tak różnych obrazów ezoteryzmu, jakie pojawiają się na kartach przywoływanych w tych rozważaniach dzieł. Rzecz jasna, największe różnice występują między zwolennikami którejś z jego form i ich oponentami. Jednak niemałe występują również między różnymi jego badaczami. Na to pytanie próbował odpowiedzieć między innymi Hanegraaf. W podsumowaniu książki pt. Esotericism and the Academy (zatytułowanym: Przywracanie pamięci) wychodzi on od pytania: „Czy może istnieć historia zachodniej ezoteryki?”, i od razu przechodzi do sugestii, że „może istnieje jedynie historia tego, co stworzyliśmy i rozwinęliśmy jako taki byt w naszej zbiorowej wyobraźni”. Nieco dalej dodaje on, że „wszystkie historiografie, z którymi się zetknęliśmy w tej książce, to intelektualne konstrukty zakorzenione w subiektywnych przekonaniach i indywidualnych planach tych uczonych, którzy je opracowali i ewidentnie odzwierciedlają one typowe dla nich przypadkowe założenia kulturowe swojego czasu i miejsca"36. Można się z tym w jakiejś mierze zgodzić. Jednak tylko w jakiejś mierze, bowiem od uczonych (również tych, którzy uprawiają nauki historyczne) oczekuje się jakiegoś obiektywizmu - jeśli nawet jest to jedynie obiektywizm względny, uwarunkowany ich osobistymi przekonaniami, wierzeniami i nastawieniami (pozytywnymi lub negatywnymi wobec tego, co sta-

${ }^{35}$ Wyróżnia on przy tym cztery jego rodzaje: „channeling transowy, automatyzm, jasnosłyszenie i channeling otwarty”. Jego zdaniem każdy z nich stanowi próbę ligitymizacji i uwiarygodnienia new-age’owskich praktyk. Por. ibidem, s. 24 nn..

${ }^{36}$ „Żaden z nich nie może twierdzić, że jest to prosty opis »ezoteryki« jako empirycznej rzeczywistości (»tradycja«, »światopogląd«, »sposób myślenia« itp.); nie odzwierciedla on czegoś, co jest dane historycznie, lecz konstruuje to”. W.J. Hanegraaff, Esoterism and the Academy..., s. $368 \mathrm{nn}$. 
nowi przedmiot badań). Rzecz w tym, aby te ostatnie nie zdominowały tak mocno przekonań badacza, że w tym, co bada, poszukuje jedynie lub przede wszystkim ich potwierdzenia. O to niełatwo jest w przypadku takiego przedmiotu badań, jaki stanowił i stanowi w kulturze zachodniej ezoteryzm, zwłaszcza wówczas, gdy się przejmuje i kontynuuje jego oświeceniowe postrzeganie i przedstawianie jako wyraz irracjonalizmu, ciemnoty i zwyczajnej głupoty. Przyznaje to zresztą Hanegraaff. Dodaje on jednak przy tym, iż takie podejście do niego trzeba odrzucić. Wskazuje on na alternatywne opcje wobec opcji oświeceniowej. Stanowi je zarówno romantyczne podejście do ezoteryzmu, jak i opcja weberowska, odwołująca się do historiozoficznej wizji „zaczarowywania świata”, jego „odczarowywania” oraz ponownego „zaczarowywania” oraz łączenia tego w historyczny proces do wyższej lub przynajmniej „innej” racjonalności ${ }^{37}$.

Kolejne uwagi i sugestie związane są z ową racjonalnością. Z jej określeniem i odróżnieniem od irracjonalności spory kłopot mieli już starożytni filozofowie, a przecież uchodzili oni i w jakiejś mierze uchodzą nadal za arbitrów w tej sprawie. W każdym razie na takie miano zasłużył przynajmniej Sokrates i jego bezpośredni uczeń Platon. Sporo już powiedziano i napisano o pojmowaniu racjonalności przez tych filozofów. Wypowiadałem się również na ten temat przy innej okazji3 ${ }^{3}$. Przypomnę zatem tutaj krótko, że pierwszego z nich namysł nad racjonalnością doprowadził w końcu do generalnego stwierdzenia, iż „wie, że nic nie wie” (zdaniem Hegla trzeba to jednak traktować jako „sokratyczną ironię” ${ }^{39}$. Natomiast drugiego z nich skłonił do wyróżnienia dwóch - pod jednym względem wykluczających się, natomiast pod innym dopełniających się - rodzajów racjonalności, tj. racjonalności Logosu (dla filozofów greckich termin ten oznaczał zarówno rozum, jak i zasadę, miarę i argument) oraz racjonalności Nous (łączonej wprawdzie również z rozumem, ale z tym, który swoje formy wyrazu znajduje w myśleniu mitologicznym). Od tej ostatniej rozumności i racjonalności jest już krótka droga do tych form ezoteryzmu, które były kultywowane w starożytności.

Za epokę kultu rozumu i związanej z nim racjonalności nie bez racji uchodzi Oświecenie. Problem w tym, że ów rozum był wówczas bardzo różnie pojmowany i generował tak różne typy i rodzaje racjonalności, że jedne z nich się dopełniają, natomiast inne wzajemnie wykluczają ${ }^{40}$. Za próbę racjonalnego uporządkowania za-

37 Zdaniem tego uczonego takie podejście do ezoteryzmu jest w opozycji do oświeceniowego postrzegania i przedstawiania go jako „kulturowego śmietnika” i prowadzi do przekształcenia tego pojęcia z kategorii negatywnej na kategorię pozytywną. Por. ibidem, s. 374.

${ }^{38}$ Por. Z. Drozdowicz, O racjonalności w filozofii starożytnej i odrodzeniowej, Wydawnictwo Naukowe UAM, Poznań 2008, s. 13 nn.

39 „Jest ona u niego pewną postacią subiektywnej dialektyki, sposobem zachowania się w kontakcie z ludźmi”. G.W.F. Hegel, Wykłady z historii filozofii, t. I, Wydawnictwo Naukowe PWN, Warszawa 1994, s. $556 \mathrm{nn}$.

${ }^{40}$ Por. P. Kondylis, Die Aufklärung im Rahmen des neuzeitlichen Rationalismus, Ernst Klett Verlag, Stuttgart 1981. 
równo starożytnych, jak i nowożytnych form rozumności i racjonalności uchodzi nie bez racji ich weberowskie ujmowanie i przedstawianie ${ }^{41}$. Można oczywiście różnie ją oceniać. Nie ulega jednak wątpliwości (przynajmniej dla tych, którzy dokonali jej szczegółowej analizy), że było to zadanie, którego wykonanie jest dosyć dalekie od doskonałości ${ }^{42}$. Zajmowałem się również analizą różnych form rozumności i racjonalności występujących w kulturze zachodniej. Po wielu latach badań przyjąłem rozróżnienie na „racjonalność afirmacji” i „racjonalność negacji”, a jako „wspólny mianownik” dla nich przyjąłem leibnizjańską zasadę, że „nic nie jest bez racji (nihil esse sine ratione). Problem nie tylko w tym, że takich racji może być wiele, ale także, a nawet przede wszystkim w tym, że mogą być i niejednokrotnie są różnego typu - począwszy od racji dostatecznej, a skończywszy na racji ostatecznej. Nie można przy tym pomijać racji wyjaśniających, uzasadniających czy przekonujących.

Tak szerokie pojmowanie i przedstawianie racjonalizmu ma zarówno swoje zalety (takie jak możliwości wpisania w jego ramy mocno zróżnicowanych zjawisk kulturowych), jak i swoje wady. Do tych ostatnich należy stawianie obok siebie lub w pewnej hierarchicznie uporządkowanej całości takich zjawisk, które w przekonaniu wielu osób albo się wykluczają, albo należą do tak kulturowo różnych światów, że nie można ich „wsadzać do jednego koszyka”. Dotyczy to zarówno zestawiania ezoterycznych wierzeń z wierzeniami tych religii, które mają nie tylko liczne grona wyznawców, ale także umocowanie społeczne w cieszących się sporym autorytetem i ochroną prawną instytucjach, jak i ich zestawiania z tymi naukami, których założenia, twierdzenia i teorie cieszą się sporym uznaniem w środowisku akademickim i mogą one być poddane zarówno weryfikacji, jak i próbie falsyfikacji. Hanegraaff odpowiadając na pytanie, co robią z ezoteryzmem zwolennicy tych religii i tych nauk, twierdzi, że zwykle traktują go jako jakiś „kulturowy śmietnik”. Rzecz jasna, oponowali i oponują przeciwko temu jego zwolennicy i oni również mieli i mają swoje racje uzasadniające ten sprzeciw.

${ }^{41}$ Zdaniem Kocku von Stuckrada Weberowska analiza transformacji kulturowych może być również pomocna w wyjaśnieniu ruchu New Age, jako „kontrreakcja na tę racjonalizację, która doprowadziła do desakralizacji przyrody i współczesnego człowieka”. Jego zdaniem, stanowi on próbę „odnowienia sakralizacji przyrody, kosmosu i materialnej rzeczywistości”. Por. K. von Stuckrad, Western Esotericism..., s. 133 i n.

${ }^{42}$ Na jej słabości wskazywał już dosyć dawno Talcot Parsons. Jego zdanie, „od momentu pojawienia się podstawowej dychotomii weberowskiej analizy na »racjonalne« $\mathrm{i}$ »nieracjonalne«, aż do chwili, gdy te ostatnie elementy traktowane są jako odchylenie od tego, co racjonalne, pojawia się tendencja do tworzenia fałszywej, teoretycznie nieuzasadnionej antytezy. Elementy, które mogą być w pewnych empirycznych przypadkach dobrze zintegrowane z racjonalnymi elementami systemu, są wtłaczane w konflikt z nimi”. Por. T. Parsons, The Structure of Social Action, McGraw-Hill, New York 1968, s. 16 nn. Alan Sica przeprowadził szczegółową analizę Socjologii religii Webera i ustalił, że tylko w części piątej tego działa (zatytułowanej Gospodarki i społeczeństwa) pojawia się kilkadziesiąt zwrotów z terminem „racjonalizm” i „wiele z nich jest wzajemnie sprzecznych”. Por. A. Sica, Weber. Irrationality and Social Order, s. $192 \mathrm{nn}$. 
W moim przekonaniu ich racji nie można ani bagatelizować, ani banalizować, bowiem może to prowadzić i niejednokrotnie prowadziło do takiego postrzegania i przedstawiania człowieka, który przez Herberta Marcuse’a nazwany został „człowiekiem jednowymiarowym”, oraz takiego związanego z tym człowiekiem światem kultury, w którym pozostawia się „otwarte drzwi” jedynie dla „jedynie słusznych racji” (wyznaniowych światopoglądowych, politycznych itp.). Jeśli jeszcze do tego dojdzie skuteczne „unieważnienie obrazu transcendencji” (nazywane dzisiaj sekularyzacją), to zdaniem przywoływanego tutaj filozofa czyni się w ten sposób świadomość tego człowieka nieszczęśliwą, a jego „uniwersum polityczne” represywnym wobec „innego” i „inności”43. Skłonny jestem podpisać się pod opinią tych badaczy ruchu New Age, którzy uważają, że różne popularne w latach 60. i 70. minionego stulecia jego formy wyrazu stanowiły sprzeciwu wobec tego rodzaju działań i ich następstw w rozwiniętych społeczeństwach zachodnich. Nie można przy tym powiedzieć, że była to „walka z wiatrakami” lub też, iż były one i są irracjonalne. Miały one bowiem i nadal mają swoje głębokie racje - jeśli za miarę ich głębi przyjmie się ludzkie pragnienie znalezienia się w innym, dużo lepszym świecie niż zastany świat współczesnej kultury zachodniej. Można dyskutować, czy dla zwolenników różnego rodzaju ezoteryzmu jest to racja dostateczna, czy też ostateczna. Można także dyskutować, czy ruch New Age stanowi jakąś istotną innowacje w kulturze, czy też jest próbą powrotu do tego świata wartości i wielkości, który we współczesnych społeczeństwach zachodnich został zepchnięty na margines. Nie ulega jednak wątpliwości (przynajmniej dla mnie), że jego racje powinny być brane pod uwagę przy próbie oceny nie tylko tego ruchu, ale także jego miejsca w kulturze - zarówno tej z przeszłości, jak i współczesnej.

\section{Literatura}

Darnton R., Mesmerism and the End of the Enlightenment in France, Harvard University Press, Cambridge 1968.

Drozdowicz Z., Filozofia włoska w epoce Odrodzenia i Oświecenia, Wydawnictwo Naukowe WNS UAM, Poznań 2012.

Drozdowicz Z., O racjonalności w filozofii starożytnej i odrodzeniowej, Wydawnictwo Naukowe UAM, Poznań 2008.

Faivre A., Access to Western Esotericism, Suny Press, New York 1994.

43 „Unieważniając pielęgnowanie obrazu transcendencji przez wcielenie ich we wszechobecną codzienną rzeczywistość, społeczeństwo potwierdza zakres, w jakim nierozwiązane konflikty stają się kontrolowane - zakres, w jakim tragedia i romans, archetypalne marzenia i niepokoje stają się podatne na rozwiązania techniczne i zanikanie. [...] Władcy świata tracą swoje metafizyczne cechy. Ich pojawienie się w telewizji, na konferencji, w parlamencie i w publicznych wystąpieniach jest całkiem niestosowne dla dramatu, z wyjątkiem dramatu na użytek reklamy”. H. Marcuse, Człowiek jednowymiarowy. Badania nad ideologiq rozwiniętego społeczeństwa przemysłowego, PWN, Warszawa 1991, s. 99 i in. 
Faivre A., L'ésotérisme, Press Universitaire de France, Paris 1992.

Goodrick-Clarke N., The Western Esoteric Traditions: A Historical Introduction, Oxford University Press, Oxford 2008.

Hanegraaff W.J., Western Esotericism: A Guide for the Perplexed. Guides for the Perplexed, Bloomsbury Academic, London 2013.

Hanegraaff W.J., New Age Religion and Western Culture: Esotericism in the Mirror of Secular Thought, Brill, Leiden 1996.

Hegel G.W.F., Wykłady z historii filozofii, t. I, Wydawnictwo Naukowe PWN, Warszawa 1994

Jung C.G., Symbols of Transformation: An Analysis of the Prelude to a Case of Schizophrenia, Princeton University Press, Princeton 1956.

Kondylis P., Die Aufklärung im Rahmen des neuzeitlichen Rationalismus, Ernst Klett Verlag, Stuttgart 1981.

Love J., Max Weber's Ancient Judaism, w: The Cambridge Companion to Weber, ed. S. Turner, Cambridge University Press, Cambridge 2000.

Marcuse H., Człowiek jednowymiarowy. Badania nad ideologiq rozwiniętego społeczeństwa przemysłowego, PWN, Warszawa 1991.

Mesmer F. A, Kurze Geschichte des thierischen Magnetismus bis April 1781, Michael Macklot, Karlsruhe 1783.

Newport J.P., The New Age Movement and the Biblical Worldview: Conflict and Dialogue, B. Eerdmans Publishing, Grand Rapids 1998.

Parsons T., The Structure of Social Action, McGraw-Hill, New York 1968.

Riffard P. A., L'ésotérisme: Qu'est-ce que l'ésotérisme. Anthologie de l'ésotérisme occidental, Robert Laffont, Paris 1990.

Schluchter W., The Rise of Western Rationalism, Cambridge Press, Berkley-Los Angeles-London 1985.

Sica A., Weber, Irrationality and Social Order, University of California Press, Berkeley-Los Angeles-London, 1988.

Stuckrad K., Western Esotericism: A Brief History of Secret Knowledge, Equinox, London 2005.

Weber M., Etyka protestancka a duch kapitalizmu, Wydawnictwo Test, Lublin 1994.

Weber M., Starożytny judaizm, w: Socjologia religii, Dzieła zebrane, Zakład Wydawniczy Nomos, Kraków 2006. 